\title{
Localizing Foreignness
}

\section{Forging Istanbul's Dragomanate}

MiniatURE PAINTING OF THE bailate, the Venetian consulate in
the Ottoman capital ca. I660, offers us a rare contemporary visual
representation of the institutional space in which dragomans were, quite literally, made (figure I.I). It depicts a two-story building, fenced off from its surroundings, and encircled by a tree-lined garden. Seated on a wooden platform in the garden with their backs to the house are three men in Venetian breeches, cassocks, and ruffs, sporting rounded orange-striped caps on their heads. At the corner, a laborer, wearing a distinctly plainer shirt, breeches, and fez, draws water from a well. Through a window on the ground floor another man, dressed similarly to the ones gathered outside, is seen holding an open book. On the second-floor veranda three figures-a bearded man and a beardless youth in simple kaftans and fur-trimmed caps and another youth in Venetian clothing - lean against the railing. The bearded man and the Venetian youth seem to be conversing, while the other youth is standing aloof.

Through minute sartorial difference, this image codifies several intersecting socio-legal, ethno-religious, professional, and age hierarchies within the bailate. It underscores the volatile identity of dragomans and apprentice dragomans, who inhabited the bailate in growing numbers in the seventeenth century, and who at once formed its institutional core and its most contentious links to the surrounding Ottoman world beyond its walls. It is hardly an accident, therefore, that the two beardless apprentice dragomans in the image are clad in prototypical high-status Venetian and Ottoman Christian garb, respectively. These two sartorial prototypes are here metonymic of two important sources of recruitment into the dragomanate. They also index the transformative capacity of long apprenticeship in the bailate to turn local Catholic youth into loyal Venetian subjects while refashioning Venetian-born citizens into effectively localized 
members of Istanbul's courtly and diplomatic milieu. A text accompanying the image reads:

Image of the house, where the Excellent Baili reside, enclosed by part of the orchard, and the hallway above, through which one walks. Below it are the rooms where usually the apprentice dragomans reside. ${ }^{1}$

The spatial and social reconfiguration of dragomans through long residency in the bailate is at the heart of this chapter, which centers on the myriad mechanisms through which apprentice dragomans were recruited, trained, employed, and imbued with a particular trans-imperial habitus. In order to appreciate the pivotal role of the bailate as a space of transformative socialization for future dragomans, the chapter first situates the evolution of the institution of the dragomanate itself at the intersection of Venetocentric, circum-Mediterranean, and Ottomancentric practices for mediating language and power. It then considers why and how dragomans became central to Venetian-Ottoman diplomacy, that is: how dragomans' sources of recruitment and modes of socialization gave shape to particular modalities of diplomatic knowledge production.

\section{Patrimonial Households and Trans-Imperial Spaces of Encounter}

Historians of the early modern Ottoman state have long noted the important role played by large elite households in entwining domestic hierarchies with imperial politics. Through their far-reaching recruitment and training programs, it has been suggested, such households institutionalized and perpetuated ethnic heterogeneity at the empire's core. ${ }^{2}$ These patrimonial households - starting with the imperial palace in Istanbul and extending to the households of military-bureaucratic elites in the provinces - served as training grounds for a large body of young cadets, who functioned simultaneously as both domestic and civil servants. Initially, candidates for the Ottoman imperial household were captured primarily through raids beyond the frontier and from among captives and prisoners of war. From the early fifteenth century, additional recruits were obtained through the formalization of the practice of devsirme, or child levy. This institution ensured the steady supply of enslaved boys for the imperial household from among the non-Muslim rural population of the provinces, especially the Balkans, where a changing percentage of boys and youth were removed 
from their parental homes and sent to the imperial center. By the late sixteenth century, however, raids, war booty, and the devşirme ceased to be the exclusive source of recruits into the imperial household. To supplement them, specialized personnel with specific skills or technical knowhow were sometimes enlisted from among converts, "foreigners" beyond the frontier, and groups in Ottoman society previously deemed "unfit" for service. ${ }^{3}$

Regardless of provenance and method of mobilization, patrimonial households had the capacity to profoundly transform their inductees. Upon recruitment, cadets underwent a lengthy and rigorous regimen of what Cornell Fleischer has termed "deracination, education, and Ottomanization," which molded them into loyal subjects suited for lifelong service to the dynast in key military and administrative roles. ${ }^{4}$ This protracted training could easily last over a decade. Recruits were first assigned to rural Anatolian (Turkish Muslim) families to learn the language and become accustomed to hard labor. Only then, after being schooled or apprenticed within the imperial household for several years, did they enter a variety of positions in the state's expanding military-bureaucratic apparatus. ${ }^{5}$ Whereas cadets' marriage was at first strictly limited, by the late sixteenth century the rules relaxed to the point that true service dynasties began to emerge, particularly among members of the imperial cavalry and other elite officeholders. Here, for the first time, membership in the Ottoman imperial household became a potentially heritable status, with sons of recruits gaining a sense of privilege by descent. These swelled the ranks and ultimately made the devşirme superfluous, leading to its de facto disappearance in the late seventeenth century. ${ }^{6}$

The transformation in household recruitment patterns at the turn of the seventeenth century and its implications for conceptions of subjecthood, loyalty, and bureaucratic professionalization have been well-documented not only in the Ottoman capital, but also in the military-bureaucratic elite households of the Ottoman Balkans, Egypt, North Africa, and the Arab provinces. ${ }^{7}$ Far less understood are the roles of recruitment into and training within expansive elite households in contemporary Venetian society. To be sure, Venetian historiography has emphasized rather the exclusivity and endogamy of the metropolitan patrician and citizen classes. ${ }^{8}$ Yet even in hyper-endogamous Venice, studies of elite households have outlined how extended, bilateral kinship orientation was instrumental in consolidating a patrician grip on political institutions, allowing families to weave 
dense networks of patronage through both the paternal and the maternal lines. ${ }^{9}$

Significantly, thus far the shared patrimonial principles and purposesthough not always actual practices - of Ottoman and Venetian elite households have gone unnoticed for the most part. This understudied confluence is especially intriguing in light of the prescribed, long sojourns at the Porte of many prominent members of Venice's elites in their youth, precisely as a political and commercial apprenticeship. It is well worth asking, therefore, how assumptions about loyalty and subjecthood were engendered by Venetian and Ottoman elite kinship and household structures, and how associated roles were inhabited and manipulated by people who were familiar with - indeed, familiars of - both.

Such familiarity was cultivated most clearly in the Venetian bailate in Istanbul, an institution that served as a model for numerous other diplomatic residences in the Ottoman capital in its functioning as a central node in the production and circulation of dragoman-mediated knowledge. In fact, the Venetian dragomanate in Istanbul and its offshoots throughout the Venetian maritime colonies and in Venice proper are a prime example of how the Venetian state adapted prototypically Ottoman mechanisms of subject-making and integration through a large elite household. The emergence and transformation of the Venetian dragomanate underscores how Venetian and Ottoman household patterns and affective ties interacted and sometimes converged in the making of trans-imperial professional cadres.

\section{Recruitment}

By its heyday in the late seventeenth century, the Venetian dragomanate came to consist of no more than a dozen families, who supplied the bailate with most of its new apprentice dragomans generation after generation. Throughout the early modern period these families intensely and repeatedly intermarried, securing their tight control over apprentice dragoman positions, which became de facto heritable. Sojourning in the bailate in the I770s, the physiologist Lazzaro Spallanzani observed that as soon as dragomans' families have sons, "they dress them alla dragomana and lead them in their father's footsteps." 10 The intergenerational transfer of skill and status embodied in dragoman positions was facilitated by the institutionalization of a specific official, subaltern dragoman rank, that of giovani di lingua (literally language youth, a calque of the Turkish dil oğlan), glossed here 
as "apprentice dragomans." "11 This neologism underscores both the strong element of apprenticeship and subordination implied by apprentices' junior position, as they honed their linguistic and diplomatic skills and shadowed more seasoned dragomans, and the reality of their service as de facto dragomans, from regularly translating official Ottoman records into Italian to their more occasional and haphazard participation in court protocol, during public ceremonies, and when substituting for their seniors on their day-today rounds to the divan and to Ottoman officials' home.

Initially, apprentice dragomans were to be recruited across Venetian territories with the explicit purpose of equipping them with the high skill and decorum required for diplomatic work in the Ottoman court. "There is no doubt," observed the bailo Paolo Contarini in 1583 ,

that the service of one's own [subjects] is more advantageous and has more public dignity than that of Turkish [i.e. Ottoman] subjects, because the [former], who are not preoccupied with showing respect, speak with daring, whereas the Turks are afraid to do so. ${ }^{12}$

Paul Rycaut, then secretary in the English embassy in Istanbul, was to make a very similar observation in The Present State of the Ottoman Empire almost a century later, pinpointing the problem of dragomans' meek speech to their compromised juridical position as Ottoman subjects:

The reason of which Tyranny and presumption in these prime Officers over the Interpreters, is because they are most commonly born subjects of the Grand Signior, and therefore ill support the least word misplaced, or savouring of contest from them, not distinguishing between the sense of the Embassadour, and the explication of the Interpreter; and therefore it were very useful to breed up a Seminary of young Englishmen, of sprightly and ingenious parts, to be qualified for that Office; who may with less danger to themselves, honour to their Master, and advantage to the publick, express boldly without the usual mincing and submission of other Interpreters, whatsoever is commanded and declared by their Master. ${ }^{13}$

Rycaut's fantasy of "a seminary of young Englishmen," however, like similar projects hatched in other contemporary embassies, was never to materialize. Even the Venetians, who made mighty efforts to send Venetian youth to the bailate, had to concede that the attempt was only partially successful, and certainly not without its perils. The bailo Sebastian Venier, 
for example, placed little hope in Venetian youth sent to the bailate to be apprenticed as dragomans on his watch:

Those [Venetians] who are of tender age, either their parents do not permit them to come here, or if they do little can be done to prevent them from falling prey to a thousand strange accidents; if they are of mature age, beyond their inability to learn languages, they have been brought up not in what I would call liberty, but rather in such license, that it is impossible to make them accommodate the customs here, and not disturb the house of the poor baili ... ${ }^{14}$

The apprentices' official title already suggests the significance attributed to young age as a precondition for the transformation presumed to result from long apprenticeship. And while most apprentices, particularly those sent from Venice, began their tenure in the bailate around the age of fifteen or eighteen, apprentices as young as ten, or even younger, were not uncommon. It was that youthfulness, however, that proved, as Venier observed, a source of many challenges, especially for sojourning apprentices hailing from faraway Venice. In fact, over the course of the seventeenth century fewer Venetians were sent to Istanbul, and fewer still successfully completed their apprenticeship in the bailate. The majority of dragoman apprenticeships became the purview of local dragomans' sons and nephews, whose sisters in the meantime married other dragomans and apprentices, forging a truly endogamous Istanbulite dragoman caste.

Such intense endogamy emerged haphazardly, since the I550s, from three very different bases of recruitment: the Venetian citizen class, the urban elites of Venice's Adriatic and eastern Mediterranean colonies, and the Ottoman (mainly Istanbulite) Catholic community. Understanding the differing ties that eventually bound these three groups to one another and to Venetian diplomacy is essential for any inquiry into their role in mediating Venetian-Ottoman relations.

In Venice, cittadini originarii (citizens by birth) formed a de facto second tier of the metropolitan elite. Men belonging to this clearly self-conscious estate were barred from officeholding and voting, but constituted the government's bureaucratic core, largely sharing patrician understandings of the state. As service in Istanbul was generally considered a stepping-stone to more prestigious government employment in Venice, numerous citizen families, with a long tradition of supplying secretaries to the ducal chancellery, were willing to send their sons into apprenticeship in the bailate. ${ }^{15}$ 
A second group of recruits to the dragomanate came from the Venetian colonial elite in the Adriatic and eastern Mediterranean, increasingly undermined by the Ottoman conquest of Venice's Dalmatian hinterland in the early sixteenth century and of Cyprus in I57I. In the aftermath of these conquests, many feudal families sought refuge in Venetian territories or in Venice itself. Placing a son in diplomatic service in Istanbul reinforced these threatened elites' claims to enduring colonial loyalty. It also offered concrete prospects for social and economic mobility by linking young apprentices with powerful patrons, and by opening up distinct future commercial opportunities in both Venice and Istanbul. ${ }^{16}$

Finally, the third and largest group of recruits to Venice's dragomanate came from the Ottoman capital's Latin-rite (Roman Catholic) community, known as the Magnifica comunità. Members of this community traced their roots to Genoese, Pisan, and Venetian settlement in Byzantium even prior to the Fourth Crusade. Permanent Genoese settlement in the bustling port district of Galata dates from the I26os. ${ }^{17}$ Local descendants of these early settlers retained their close ties to the city's political and commercial nerve centers after the Ottoman conquest of I453. ${ }^{18}$ It was in the second half of the sixteenth century, however, as several foreign embassies relocated to Pera (today Beyoğlu), a leafy hilltop quarter just behind Galata, across the Golden Horn from the sultan's Topkapi palace, that the bailo began recruiting his dragomans from among members of several prominent local Catholic families.

In joining his large household, permanently based in Pera after I57I, local dragomans gave the bailo direct access to the area's centers of power, while increasing their own status. The local prestige of the dragoman's position is evident from the tight correspondence between its holders and the highest officers - priors and sub-priors — of the Magnifica comunitàwho oversaw the community's significant real estate holdings and were entrusted with negotiating with Ottoman authorities periodic maintenance and repairs for the area's numerous Catholic churches and convents. Between 1570 and 1670 , Venetian dragomans or their immediate kin served as priors or sub-priors of the Magnifica comunità thirty-two times, for a cumulative total of eighty-eight years. Between I670, when elections became more sporadic, and 1705 (the latest date for which information is available), ten of thirteen Community officials were dragomans, though not necessarily Venetian. Dragomans also served in other capacities in local Catholic churches. In I626, Giovanni Antonio Grillo, the Venetian grand 
dragoman, was appointed Procurator of St. Francis. That same year, two members of another dragomans' family, Matteo and Bartolomeo Piron, became Procurators of St. Peter and St. George, respectively. ${ }^{19}$

From local recruits' perspective, Venetian employment spelled not only a steady income, but a source of authority within the shrinking, conflict-riddled Catholic community. Venetian employment served, furthermore, as legal protection, granting dragomans immunities and exemptions from Ottoman law, at least in principle. ${ }^{20}$ Most important, dragoman posts offered several distinct familial advantages. A dragoman was well positioned to keep relatives abreast of political, economic, and military developments both at home and abroad. Access to such timely news was essential to long-distance traders. Beyond trading in information, dragomans' intense and varied contacts among the political-cum-commercial elites of Istanbul and Venice (or, London, Marseille, and Amsterdam) greatly benefited merchant relatives by offering concrete business opportunities. For such merchants, the ability to extract profit depended on accessing often highly monopolistic markets as well as on securing preferential tax levels therein. Both depended on contracting deals (and, ideally, forging partnerships) with foreign merchants. ${ }^{21}$ The connection between English, French, or Dutch merchants and their respective embassies was more or less explicit, as the former practically ran the latter, or at least retained a high degree of financial leverage over it. ${ }^{22}$ If in the Venetian case the power dynamic was not as simple (certainly by the seventeenth century), the bailo still had to cultivate the good will of his advisory council, which consisted of locally based Venetian merchants.

From the perspective of Venetian officialdom, the recruitment of dragomans from among Pera's most powerful Catholic families could curb, at least partially and temporarily, French and Papal inroads into the community. The strategic and iconic significance of the Magnifica comunità was well recognized by the various Catholic powers of the period, all of whom vied to claim their protection of specific Christian Ottoman holy sites and institutions. ${ }^{23}$ More important, it gave Venice access to diffuse social networks that facilitated the elusive task of information gathering across Ottoman territories, particularly given Pera families' frequent marital ties to the Catholic and Orthodox elites of the Aegean and Ionian, the Dalmatian coast, and the Danubian principalities, as well as the Ottoman capital itself.

In recruiting apprentice dragomans, the Venetians gave clear preference to the sons, sons-in-law, and nephews of acting and former dragomans, 
making them de facto hereditary posts. ${ }^{24}$ Local families were keenly aware of this practice and the inroads into dragoman apprenticeships in the bailate that kinship ties provided. When a local dragoman or apprentice passed away or retired from service, his relatives would immediately petition the bailo to take another kinsman in. For example, when Ippolito Parada died of the plague only a few months after starting an apprenticeship in I637, his family promptly asked that he be replaced by his fifteen-year-old younger brother, Michele. The bailo Alvise Contarini, who approvingly forwarded the request to the Senate, suggested that "Your Serenity could do no greater work of charity than this." ${ }^{25}$ On another occasion, the dragoman Giovanni Battista Navon, whose father, Pasquale, and brother Tommaso had already served in that office, petitioned to have his son Alessandro admitted into the bailo's service as an apprentice dragoman. Navon did not fail to mention his father-in-law, Marcantonio Borisi, who had been executed by the Ottomans while in Venetian service, and the stipends disbursed to his now-deceased wife and her sisters in recognition of Borisi's merits. Citing both families' long service, the bailo recommended admitting Alessandro so that "excited by this stimulus of public kindness he will diligently apply himself to his studies as faithfully and devotedly as is typical of his family [casa]."26

This mechanism of recruitment proved very effective, and within a couple of generations the Venetian dragomanate was populated overwhelmingly by members of the Catholic community of Pera. Throughout the late-sixteenth and seventeenth centuries several of the most distinguished local Catholic families had at least one son employed as a Venetian apprentice dragoman at almost any given moment. This system of virtually guaranteed employment to certain local families reproduced on a smaller scale the Venetian strategy of granting citizens by birth a monopoly over specific positions in the state bureaucracy, forging alliances and securing goodwill and collaboration. ${ }^{27}$

Table I.I and figure I.2 show the different juridical composition and kin resources of the bailate's apprentices and dragomans from the late-sixteenth to the early-eighteenth centuries. Of a total of thirteen Venetian citizen families represented in the dragomanate, six produced only apprentices who failed to achieve dragoman rank. ${ }^{28}$ In contrast, all seventeen Ottoman families represented in the pool secured at least one dragoman appointment. ${ }^{29}$ If we consider that, unlike Venetian citizens, many Ottoman and Venetian colonial families represented in the dragomanate had multiple members in service throughout the period-some up to half a 
TABLE I.I Juridical composition of the Venetian dragomanate in Istanbul, I570-I720

\begin{tabular}{lccccc}
\hline \multicolumn{1}{c}{ Rank } & $\begin{array}{c}\text { Venetian } \\
\text { citizens }\end{array}$ & $\begin{array}{c}\text { Venetian } \\
\text { colonial } \\
\text { subjects }\end{array}$ & $\begin{array}{c}\text { Ottoman } \\
\text { subjects }\end{array}$ & Unknown & $\begin{array}{c}\text { Total } \\
\text { families }\end{array}$ \\
\hline $\begin{array}{l}\text { Apprentice- } \\
\text { only families }\end{array}$ & $7^{\mathrm{b}}$ & $2^{\mathrm{c}}$ & - & $1^{\mathrm{d}}$ & 11 \\
$\begin{array}{l}\text { Dragoman families } \\
\text { Total families }\end{array}$ & $6^{\mathrm{e}}$ & $4^{\mathrm{f}}$ & $17^{\mathrm{g}}$ & $2^{\mathrm{h}}$ & 28 \\
\hline
\end{tabular}

a. Excluding families with both apprentice dragomans and dragomans.

b. Garzoni, Scaramelli, Torre, Tosi, Velutello, Vico, and Zon.

c. Agapito and Ausonio.

d. Cornaro, likely Venetian citizens or subjects.

e. Alberti, Bon, Darduin, Imberti, Marucini, and Vecchia.

f. Borisi, Brutti, Carli, and Tarsia.

g. Balsarini, Coressi, Fortis, Gioveni, Girachi, Grillo, Gulianò, Mascellini, Navon, Negroni, Nicolini, Olivieri, Parada, Piron, Ralli, Salvago, and Sanguinazzo.

h. Calavrò-Imberti (possibly of Istrian/Venetian colonial or Venetian citizen provenance) and Scassi.

dozen or more - their relative share of the dragomanate becomes significantly greater: in the I50-year period analyzed here, only seven bailate dragomans hailed from Venetian citizen families, and, with the exception of the Marucinis early in the period, every Venetian citizen dragoman was an "isolate," with no blood relatives employed as either apprentices or dragomans..$^{30}$ In contrast, the four Venetian colonial families in the dragomanate had a total of twenty-four individuals in service, and the seventeen Ottoman families at least fifty-five. ${ }^{31}$ Venetian citizens, then, accounted for only I6 percent of the dragomanate in this period (fifteen out of a total of ninety-four individual apprentices and dragomans), compared with 25 percent Venetian colonial subjects and nearly 59 percent Ottoman subjects, respectively. That dragomans tended to be lifelong bailate employees, whereas apprentices typically worked in the bailate for a decade or less, means that Ottoman majority at any given time was even more pronounced than can be gleaned from simple percentages or head counts.

Of course, representing dragomans through their membership in decidedly patriarchal and patrilineal families hardly gives a complete picture 
of their multiple, at times trans-imperial kin relations. But it does provide a reasonable shorthand for individuals' juridical status (acquired largely through patrilines), and the growing dominance of Istanbul's Catholic elite in the Venetian dragomanate. It is also noteworthy that all four families of Venetian colonial subjecthood represented in the dragomanate-Borisi, Brutti, Carli, and Tarsia - were intermarried among themselves as well as among Catholic Istanbul's elite families, including several other dragoman dynasties, as figures I.2 and I.3 further demonstrate. Figure I.2 reveals the significantly greater propensity of Ottoman families represented in the Venetian dragomanate to contract marriages with other such families, as well as with Venetian colonial dragoman families, compared to Venetian citizen ones. Figure I.3 broadens this picture to underscore Catholic Pera's intense endogamy across dragomanates, as well as the integration of foreign dragoman families (Venetian colonial and other) into that milieu through marriage. Here, too, Venetian citizen families are the outlier.

This dynamic suggests that by the late sixteenth century the institution of the bailate, albeit of much longer, Byzantine roots, came to weld classical Venetian patterns of endogamy and social reproduction with Ottoman practices of exogamous recruitment and training. On the one hand, admission into Venetian service in Istanbul - not unlike other positions in Venice's expansive state apparatus - relied heavily on kinship and descent. On the other, it entailed the restructuring of these same familial ties. For upon entry into service, young apprentice dragomans were removed from their (predominantly Istanbulite) homes and from the domestic care of their (predominantly Greek-speaking) mothers, and placed into the allmale, Italianate space of the bailate. There, for the next seven years or more, they were entrusted into the paternal care of their dragoman fathers, uncles, older brothers, and, of course, the bailo himself. The latter, although customarily ignorant of Turkish, personally supervised his apprentice dragomans' linguistic progress and reported on it in his periodic dispatches to the Venetian Senate and in his comprehensive relazione upon return from office. ${ }^{32}$

The discussion so far has suggested a simple, tripartite division of the dragomanate into denizens of Venetian, colonial, and Istanbulite Catholic families. This division is in line with the logic of the early modern Venetian state itself, which carefully distinguished between citizens, subjects, and non-subjects, each possessing a supposedly inherent and fixed degree of affinity to the Venetian state, and a set measure of willingness to put the 
state's interests before one's own. Suspicion of the supposed disloyalty and dishonesty of Pera-born dragomans, which would characterize Venetian debates about the dragomanate throughout the seventeenth and eighteenth centuries (and permeates some modern scholarship too), resulted in repeated, if largely failed, attempts to secure quotas for Venetian secretaries' sons among apprentice dragomans, and to facilitate training programs in Venice prior to dispatching youth to Istanbul. ${ }^{33}$ Indeed, the recruitment of Venetian citizens and colonial subjects as apprentice dragomans was intended precisely to counteract the proverbial disloyalty of Pera-born dragomans who were, after all, Ottoman subjects.

Yet the very division of the dragomanate into Venetian citizens, colonial subjects, and Istanbulite non-subjects was much eroded by the forms of sociability engendered by the bailate and the wider Ottoman city. So much so that by the seventeenth century the boundaries between the three groups became increasingly difficult to maintain. Venetian subjects and citizens sent to be trained in Istanbul could "go native" in ways unforeseen and unappreciated by their employers. Some embraced Islam, quit the service, and sought employment elsewhere in the Ottoman capital. For example, in the span of just three years, from I627 to I629, Venice lost three of its Venetian-born apprentice dragomans. Camillo Garzoni was convicted of an unnamed crime (possibly leaving Istanbul without the bailo's permission), exiled to Zara (Zadar, today in Croatia) for three years, and barred from public office for life. Another apprentice, Fontana, converted to Islam. A third, Antonio Torre, also became Muslim, leaving behind a long list of creditors. ${ }^{34}$ Some apprentice dragomans took local concubines or lovers in clear transgression of expected affective boundaries, ${ }^{35}$ while others still were absorbed into the Latin community of Pera through marriage, acquiring in the process in-laws from among more senior dragomans or other wealthy and well-connected denizens. Out of dozens of Venetian citizens who apprenticed in the bailate over the century, only a handful became dragomans.

For those who did, marriage into local families facilitated quick integration into the Latin community. In fact, by the mid-seventeenth century, the high degree of intermarriage among the three groups of Venetian dragomans in Istanbul led to the establishment of veritable dragoman dynasties, more or less permanently settled in Istanbul despite their diverse roots across Ottoman and Venetian territories. Dragomans' intergenerational and trans-imperial bonds were both capitalized upon by dragomans 
themselves and seen by their Venetian patrons as vital to the success of their enterprise in the Ottoman capital.

The high degree of endogamy and integration across juridical lines is further indicated by the numerous cases of colonial émigré dragomans who came to assume prominent positions in the Latin community. Cases in point are those of the Venetian dragoman of Albanian and Istrian origins Christoforo Brutti, who was appointed sub-prior of the Magnifica comunità in I623, and Brutti's nephew, Christoforo Tarsia, born in Venetian Capodistria (Koper, now in Slovenia), who in I652 became the community's prior. ${ }^{36}$ Whereas the granting of the prestigious title of prior or sub-prior was a clear sign of these parvenus' ultimate recognition as elite members of the local community, it also marked their reciprocal adoption of a local, deeply endogamous practice that wedded elite status, service to the Venetian bailate, and communal title-holding.

From the Ottoman state's point of view, too, dragomans were both "foreign" by virtue of serving foreign embassies, and "local" by virtue of their numerous relations in the Ottoman capital and provinces, and their wives' and sisters' at times significant real-estate ownership in the city. ${ }^{37}$ Dragomans themselves often complicated this juridical situation further by placing different sons with different embassies, thus making claim to various forms of foreign protection, if not outright subjecthood. For example, in the late-sixteenth and early-seventeenth centuries, members of the Olivieri family worked in both the French and Venetian embassies. Nicorosio Grillo, a cousin of the Venetian grand dragoman Giovanni Antonio, was employed by the Dutch ambassador Cornelis Haga in I6I6. Other local families, including the Navon, Piron, and Parada, similarly had some sons working for the Venetians and others for the French, the English, the Dutch, and the Habsburgs. ${ }^{38}$

Officially, the Venetians disapproved of their dragomans' immediate relatives working for other powers for fear of espionage. However, extended kin and friendship networks offered dragomans vital access to local and inter-imperial information, often proving beneficial to their Venetian employers too. Panaiotis Nicousios (I6I3-I673), for example, who served the Habsburg legation in Istanbul and later became Ottoman grand dragoman, maintained a decades-long friendship with Ambrosio Grillo, as well as other Venetian dragomans and baili, providing vital information on political maneuvers in other embassies and the chambers of the grand vizier himself. ${ }^{39}$ 
Over time, even the long-standing chasm between Istanbul's Catholic and Orthodox (Phanariot) elites - though ideologically still powerful — was sufficiently eroded through intermarriage that some Venetian dragomans became directly related to the Porte's Phanariot grand dragomans of the Mavrocordato and Ghika families. ${ }^{40}$ The two sons of the Ottoman grand dragoman Alexander Mavrocordato (in office from I673), Nicholas (grand dragoman from I689) and Yanaki (grand dragoman from I709), married Cassandra Cantacuzeno and Zamfira Gulianò, Ambrosio Grillo's granddaughter and niece, respectively. Nicholas and Cassandra's son married Maria Gulianò, likely Zamfira's niece. By the eighteenth century, the Mavrocordatos became related through marriage to the Ralli family, several of whose sons served as Venetian dragomans. ${ }^{41}$ The advantages of such unions for Venetian diplomacy were hardly lost on the baili. Upon Cassandra Cantacuzeno's marriage to Nicholas Mavrocordato in August I700, the bailo Lorenzo Soranzo reported to the Senate that he had taken the opportunity to cultivate both families' good will by sending Cassandra a gift of four robes "with other gallantries."

The Phanariot connection's significance goes beyond purely genealogical reasons. It was dragomans' Phanariot kin - especially mothers - who facilitated early acquisition of Greek at home and who greased the wheels of the highest echelons of the Ottoman government, where Phanariots played a decisive role. Venetian dragomans' Phanariot connections - their mothers' membership in the post-Byzantine Orthodox aristocracy-also bolstered their elite status. The prestige and power enjoyed by such Orthodox Istanbulite elites, modeled on Ottoman forms of the grandee household, were recognized by courtly society even more than that of their Catholic counterparts. ${ }^{43}$

The long-term employment of several entry-level apprentice dragomans who displayed only minimal linguistic skills but who were well connected in Istanbul attests to the political usefulness of maintaining members of various local elites on the bailate payroll. In an extensive report on dragomans' performance in I64I, two outgoing baili, Pietro Foscarini and Alvise Contarini, cautioned against discharging any from service, regardless of poor performance, since they would immediately be recruited by the French and English. ${ }^{44}$ A dispatch by the Venetian Resident (de facto bailo) Giovanni Battista Ballarino in I655 confirmed that the aging Giovanni Piron, who had been employed as an apprentice dragoman for twenty years, had finally mastered some languages, and endorsed his petition for 
promotion to the level of dragoman. Yet in I664 Piron, aged seventy-five, was still listed on the payroll as an apprentice. According to Ballarino, for the previous six years Piron had visited the bailate only at Easter and Christmas. Given his brother Antonio's position as an English dragoman, and Giovanni's fast friendship with Giorgio Draperis, the English grand dragoman, Ballarino considered his absence from duty an advantage, since it kept the disgruntled apprentice from disclosing sensitive information to Venice's commercial rivals. ${ }^{45}$

\section{Training}

The Venetian dragomanate's tight endogamy, which sometimes pulled Venetian recruits into Ottomancentric milieus, could also operate in the reverse, imbuing local recruits with cultural frameworks, bodily repertoires, and social contacts that signaled their incorporation into a Venetocentric trans-imperial project. A former dragoman turned abbot, Antonio Olivieri, provides intriguing vignettes into the world of the bailate in the later seventeenth century and its transformative capacity for local recruits. Born in I655, Olivieri joined the bailate as an apprentice dragoman ca. I670. The scion of a local Catholic dragoman dynasty, Olivieri was the son of Giovanni, a long-time Venetian dragoman, and the grandson and great-grandson of Carlo Olivier and Domenico, senior French dragomans at the turn of the seventeenth century. His mother, Cassandra Cantacuzeno, on the other hand, was the daughter of a distinguished Orthodox Phanariot family ${ }^{46}$ In his memoir, Olivieri describes how the foreign embassies of Galata and Pera jointly sponsored a large masquerade ball of 150 persons for the 1676 carnival season, and then, in an explicit effort by the French and Venetian representatives to outdo one another, commissioned lavish, public theatrical productions the following year, in which some dragomans also performed. Olivieri himself was asked by the bailo Morosini to participate in a production of Don Giovanni. ${ }^{47}$ Despite Olivieri's protestations that his Italian was poor and that he would become the laughingstock of the community, he was left with no choice but to recite the prologue and to play the sheriff who attempted to prevent Don Giovanni from visiting a bordello.

Beyond the reaffirmation of hypersexual heteronormativity, a prerequisite of the bailate's strictly homosocial space (despite periodic breaches), this theatrical production partook in a process of turning local youth into 
distinctly "cosmopolitan" courtiers. Of course, the use of public spectacle to convey courtly power was not unfamiliar to denizens of the Ottoman capital - the Porte sponsored such spectacles on various occasions, and even commissioned their immortalization in lavish albums. ${ }^{48}$ But the specific genres chosen by the bailo — masquerade and comedy - were distinctly foreign. 49 "Don Giovanni" itself was a work whose diverse iterations across Spanish, French, and Italian stages (and, eventually, in Habsburg Central Europe) made it a particularly potent sign of cosmopolitan cultural connoisseurship. In the immediate context of the performances orchestrated by Istanbul's embassies in 1676 we should note the trappings of lavish costumes and masquerade. These departed sharply from the clear demarcation of hierarchy, position, and communal belonging through sartorial regimentation that characterized early modern Ottoman urban society in general, and dragomans' livery in particular. As significant were the temporary redrawing of communal boundaries as to include all embassy staff, and the designation of the public space of the embassy district as culturally foreign by importing fashionable theatrical genres and mounting stages, backdrop scenery, and other visual props.

Beyond the topsy-turvy spacetime of carnival season, the process of socializing future dragomans continued to unfold more mundanely through protracted apprenticeship and residence in the bailate. As their name suggests, most giovani di lingua started their apprenticeship in their teens. Initial legislation in I55I set apprentices' minimum age at twenty, but over the years, children as young as eight or ten were regularly admitted. ${ }^{50}$ Teenage diplomatic employment was hardly unusual at the time. French apprentice dragomans' average age upon arrival in Istanbul was seventeen to nineteen, and the initial decree signed by Louis XIV's minister Jean-Baptiste Colbert had envisioned an even earlier start, at nine or ten. ${ }^{51}$ Youth employment was customary in other settings too. Starting in the I630s, the colonial administration of seventeenth-century New Spain preferred very young employees, as Mark Burkholder observes. Despite their lack of maturity and inexperience, he contends, young bureaucrats held the prospect of long years of future service. ${ }^{52}$ This was vitally important for dragomans, whose protracted linguistic training and upkeep were particularly costly.

Apprentice dragomans' youthfulness nevertheless posed challenges. During their initial sojourn in the bailate they had to undergo not only language training, but comprehensive general education as well. ${ }^{53}$ Various 
baili sought different solutions to this problem. In I577, the bailo Giovanni Correr endorsed a proposal by the Turkish language instructor in his house to go to Venice to train young children there before they are sent to Istanbul. ${ }^{54}$ In a dispatch to the Heads of the Council of Ten a few years earlier, the bailo Antonio Tiepolo went so far as to suggest that the two apprentice dragomans in his house at the time, Matteo Marucini and Marchiò Spinelli, be sent to live outside the bailate, "in the house of one of the Turkish dragomans," to give them better opportunities to practice the language. Tiepolo did not elaborate on the identity of the proposed foster family, but the very idea of sending Venetian youth to live outside the bailate was novel (although "Turkish" here is curious, it could be understood as meaning local Ottoman Christians rather than Muslims, let alone ethnic Turks). Tiepolo suggested that in this way the two youth might gain command of the language in a year or two. ${ }^{55}$ This estimate is interesting, since by that point Marucini and Spinelli had lived in Istanbul for over six years. Yet the proposal, endorsed by the two apprentices themselves, was apparently rejected by the Venetian authorities. And although in I623 the Senate favored proposals to send apprentices to be schooled in an Armenian college, suggesting that "staying in a place where one only speaks, reads and writes in Turkish, it is to be believed that the fruit hoped for will be produced faster," the plans remained unrealized. ${ }^{56}$

Upon appointing two apprentice dragomans, Bernardin Zon and Camillo Garzoni, in 1625 , the Senate repeated verbatim the decision to have them attend an Armenian college in Istanbul. ${ }^{57}$ Yet no indication survives of any Venetian apprentices ever actually attending the Armenian colleges in either Istanbul or Izmir. In fact, after Venetian dragoman apprenticeship in Istanbul was instituted by law in I55I, all incumbents were strictly confined to the bailate for the duration of their apprenticeship, normally lasting seven years or longer. This held true even for local apprentices who, in order to become dragomans, needed to be re-socialized as Venetian subjects first.

Formally, then, an apprentice dragoman's training began upon entry into the bailate. In reality, however, many had started their preparation long before. Venetian citizens often trained as secretaries in the ducal chancellery in St. Mark's Square for several years prior to traveling to Istanbul. Peraborn youth, especially the sons and nephews of active dragomans, received home instruction in several languages before they were formally admitted to the ranks of apprentices. In a I700 petition, the dragoman Giacomo 
Tarsia, the son and younger brother of several dragomans in Venetian service, described how his two sons, eighteen-year-old Christoforo and thirteen-year-old Giovanni Battista, had already learned several languages at home. Christoforo, argued the proud father with perhaps a tinge of hyperbole, had already mastered Italian, Latin, French, Greek, Turkish, Persian, and Arabic. ${ }^{58}$ Giacomo himself had been taught languages at home by his father, Christoforo, in the I66os. ${ }^{59}$ These were hardly exceptional cases. In I672 the Venetian traveler Cornelio Magni observed the early linguistic training of Pera's future dragomans:

[I]t is certainly quite remarkable seeing that not only adults, and older men, but also young children as soon as they learn to babble loosen their tongue in three of four very different languages, and these in perfection.

The Greek language is their original, being the common spoken idiom of the country, and in it they are educated by their mothers, who cultivate that language. ${ }^{60}$

Early modern Istanbul's plurilingualism was pervasive. Yet it is important to point out that dragoman households often used Greek alongside (or instead of) Italian for everyday interaction, whether due to marriage into local Orthodox Phanariot or Catholic émigré families from Greek-speaking islands, or to Greek's enduring cultural prestige among post-Byzantine elites. In I6I4 the Roman traveler Pietro della Valle, while sojourning in Istanbul, noted that "there remain in Pera few families of ancient times, who are all Greek in their clothes and customs, and preserve the Latin rite and Italian language, concurrently with the Greek idiom.." In I680, an Irish vicar apostolic, John Baptist Burke, listed Pera's dragoman households in general, and the Tarsias in particular, as "Greeks of the Latin Rite." 62 Eighteenth-century parish records from Galata's largest Catholic church, SS Peter and Paul, show that "Greeks" formed the lion's share of this French-sponsored church's parishioners (e.g., 68 percent and 6I percent of brides and grooms, respectively; 63 percent and 55 percent of mothers and fathers of baptized children; and 55 percent and 34 percent of female and male deceased). The term "Greek" here clearly referred to language rather than confession, as the parishioners of SS Peter and Paul were Catholic, mostly members of the local Latin-rite community (the former Magnifica comunità, dissolved in I680), or émigrés from the islands of Chios, Tinos, and Syros. As Edhem Eldem shows, this interpretation is further borne out 
by the strong endogamy within this Greek element of the community, with some exogamy vis-à-vis French residents in Istanbul ${ }^{63}$ The term "Greek," however, like the term "Turk," derived some of its potency precisely from its bivalency as both an ethnolinguistic and a religious marker. This bivalency was the source of much anxiety among early modern sojourning diplomats, while proving invaluable to dragomans' access to Greek-speaking Ottoman elites.

As significant as Greek was as a marker of local cultural fluency, it was Ottoman Turkish that was understood as the sine qua non of dragomans' training. The 155I decree regulating apprentice dragomans' training entrusted their instruction to a local Catholic resident of Pera, Pietro Maruffo. ${ }^{64}$ But very soon the bailo hired a Muslim Turk to serve as cozza (from Turkish hoca, schoolmaster) for several hours a day. Periodic accounts found in baili's dispatches concerning apprentices' education suggested only limited progress, in part due to the lack of a shared language between the teacher and his students, in part due to the former's personality and pedagogical shortcomings (drinking problems and a reluctance to force unwilling students to attend classes were among the recurring problems cited). In 1577 the bailo Giovanni Correr reported that the hoca, one Mehmed Çelebi, had good command of Italian and a pleasing manner. ${ }^{65} \mathrm{He}$ also seems to have been perennially in debt. A power of attorney granted by the dragoman Matteo Marucini to Girolamo Alberti in $158 \mathrm{I}$ authorized the recovery from Mehmed of a debt of 2,I00 aspers. ${ }^{66}$ The dragoman Stefano di Gioveni's 1599 will similarly mentions that the hoca owed him 6,000 aspers. ${ }^{67}$ In later decades things seem to have gone from bad to worse. A I64I report on the performance of dragomans by the bailo Girolamo Trevisan praised the Turkish teacher for his erudition, knowledge of Ottoman law, and refined Arabic, Persian, and Turkish. But it acknowledged that the hoca

Does not understand any Italian or Greek. Thus he would not be fit to teach the beginners, because they will not understand each other, but for those who have some foundations he is very useful in perfecting them when they apply themselves to it. He visits the house, but does not have a designated room in which to hold classes; no such room is available, [therefore] he teaches whoever comes to him, but will neither reproach, nor seek those who do not; he is not without his great faults; he is so dedicated to wine that he is often overcome by it, and 
with age, which advances, this vice always grows. He dresses like a Dervish, which is like a religious habit, but he is not scrupulous at all about [religious] law, and it is widely agreed, that he doesn't care much about either [law or religion], which is why, in the many years he has served the House he has never said a word to any of his students regarding matters of religion, or any Muslim persuasion, as anyone very zealous could easily have done. ${ }^{68}$

Two months later, the baili Pietro Foscarini and Alvise Contarini stressed even further the shortcomings of apprentices' current training:

Because the apprentice dragomans, especially those of the land, have a great need to learn to speak good Italian, with which they could then more easily improve their Turkish, since the hoca, otherwise valorous in the Turkish, Persian, and Arabic languages, does not understand Frankish [i.e. Italian], and so neither one nor the other knows the validity of words, and their true signification, the young apprentices lose their first two or three years of studies, or spend them with very little profit: We remind you with all reverence, how necessary overall it is, to provide these youth with a person, who will instruct them in the Italian language, and will also teach them to write, with good phrases and characters, which is very important for the translation of letters and other writings which are sent from Venice, and the ones that the baili write: This person could be either the Chaplain of the current Excellent Bailo, with some increase in salary, or one of the Franciscan or Dominican Fathers that are sent to Istanbul, who as [Venetian] subjects also receive some annual monies, which the Cottimo fund of Your Serenity pays them; and it could in that case be asked of their superiors to send for that effect someone experienced in belles lettres, and in the most appropriate conditions of such a position. ${ }^{69}$

A dispatch in I643 similarly reported that due to space shortage the hoca had no place to hold classes, and had therefore taken to arriving in the house only around lunchtime and leaving shortly thereafter. ${ }^{70}$ A room was evidently found, finally, to accommodate the hoca Omer Effendi and his students, for in I655 Secretary Ballarino's account books list expenses for fitting the room, as well as for the apprentice dragomans Brutti and Leonardo Tarsia's purchases of Turkish books. ${ }^{71}$ 
Yet the problems with apprentices' training did not consist only of space and teaching materials. As the baili's dispatches suggest, mastery of Ottoman Turkish was but one component of apprentices' required training. The youngest, barely literate in any language, needed basic schooling. Local-born youth required instruction in Italian and Latin as much as in Ottoman, as their home language was often demotic Greek (and, far less frequently, Slavic or Armenian). Early language instruction proved advantageous given the limited pedagogical resources available for formal training programs in the bailate. Most critically, unless arriving from the Venetian chancery, apprentices had to master the basics of diplomacy, letter-writing, and secretarial work as well, for which abundant pedagogical literature existed in Italian.

Part of the solution to the shortcomings of the hoca's formal instruction was found in the apprenticeship system itself: classroom learning was often supplemented by substantial on-the-job training (shadowing senior dragomans on their daily runs, observing, and imitating) and by lengthy appointments to less prestigious posts in Venice's Mediterranean and Adriatic colonies prior to assuming the rank of bailate dragoman. Anecdotal evidence for the regularity of this de facto cursus honorum abounds in apprentice dragomans' petitions for promotion. In his 1652 petition to be appointed dragoman, Ruggiero Tarsia detailed his lengthy career as an apprentice for a whopping twenty-four years. According to Tarsia, after taking up Ottoman Turkish, he was posted in Crete, Corfu, and in the navy. He participated in eleven trips to Istanbul to accompany the Venetian baili Girolamo Trevisan, Pietro Foscarini, and Alvise Contarini on their journeys to and from the Ottoman capital, substituted for Grand Dragoman Grillo when the plague struck the latter's house, accompanied the road dragoman Giovanni Battista Salvago on his trips to Venice to assist Nicolò Dolfin on his (never to materialize) trip to Istanbul, and also served as a public interpreter both in Venice and under Captain General Foscolo in Sebenico (Šibenik, now in Croatia) and Zara. ${ }^{72}$

The Venetian method of apprentice training in situ was by far the most systematic among Istanbul's contemporary embassies. Anecdotal evidence suggests that others often attempted (sometimes successfully) to poach dragomans who had undergone the Venetian training system. As late as the I670s some aspiring dragomans of large legations such as the French still resorted to improvisation, supplementing whatever limited linguistic and diplomatic training they had acquired prior to arriving at the Porte 
with ad hoc private Arabic, Persian, and Ottoman tutors. ${ }^{73}$ It was only from the I670s onward that other powers began to develop in earnest their own dragoman schools, with varying degrees of success.

Given the many complications associated with training apprentices in Istanbul, it is remarkable that a school for Ottoman language was never established in Venice. Early on, the Senate's appeal to the bailo Antonio Erizzo (I555-I557) to ship Ottoman-language instructional books to Venice was declined on the grounds of their cost. ${ }^{74}$ Two decades later, in I577, it was actually the bailo, Giovanni Correr, who enthusiastically relayed to the Senate the hoca's proposal to relocate to Venice and establish a school there. Correr endorsed the proposal, arguing that since children were quicker language learners, instruction in Venice would allow them to "learn Turkish as their maternal language." Correr added that the teacher had good manners and was fluent in Italian. Furthermore, the costs of his upkeep in Venice surely would not exceed those of accommodating apprentices in the bailate. ${ }^{75}$ But the Senate never approved the move. Fifty years later, in I627, it decreed a search for a Turkish instructor for young apprentices in Venice, specifying, however, that he must be Christian, perhaps Greek or Armenian. ${ }^{76}$ Such a person was never found. Instead, throughout the period, in order to become dragomans Venetian-born apprentices had to spend much of their youth in Istanbul.

Several other legations sought to adopt and adapt the Venetian practice of sending young apprentices for long sojourns in the Ottoman capital. Starting in I626, French apprentice dragomans were lodged and trained in the Capuchin convent adjacent to the French embassy in Pera. Initially, the program meant to enroll between eight and twelve students annually, but these numbers clearly were not met. In I669, a royal decree established that six Jeunes de langues would be sent to Istanbul annually, to be schooled by the Capuchins. ${ }^{77}$ Other embassies, too, attempted, mostly unsuccessfully, to establish training programs of their own. Starting in the late sixteenth century, the Polish crown periodically sent young nobles to Istanbul on a bursary in order to learn Ottoman and diplomacy at court - on more than one occasion under the Polish converts turned imperial dragomans, Ibrahim Bey and Ali Ufki Bey. ${ }^{78}$ A mid-seventeenth-century proposal by a dragoman in Polish service to establish a school in Warsaw to train future diplomats, missionaries, and merchants (to be recruited, respectively, from among Polish nobles, clergy, and commoners) never materialized. ${ }^{79}$ It may well have inspired, however, future efforts undertaken by the Habsburgs 
in Vienna and the Bourbons in Madrid to systematize dragoman training programs, which, like the Polish school, emphasized fencing and good manners, as much as Ottoman grammar.

Most of these attempts faltered, as efforts to send youth to Istanbul met with very mixed pedagogical results, while proposals to recruit a suitable faculty and instructional materials for use outside the Ottoman Empire proved financially or politically inexpedient. In the French case, this led the government to embark on a radically different program of training. In I700 twelve scholarships were established for "Oriental children" to study at the Jesuit Collège-Louis-le-Grand in Paris. By I72I, all boys destined for dragoman apprenticeships, whether hailing from French or Ottoman-Christian families, were to be trained at the Parisian Jesuit college first, and only then, after about eight years, travel to Istanbul. Although this program underwent various modifications over the years (and eventually admitted an equal number of "Levantine" and French students), it kept intact the basic model of extensive formal linguistic training in Latin, Ottoman, and Arabic in the French metropole prior to going to Istanbul. ${ }^{80}$ This method of training officers in the metropole bears close similarity to later colonial policies, both French and other. ${ }^{81}$ Even earlier, this model further inspired similar programs elsewhere in Europe. A late-seventeenth-century attempt by the English Levant Company to send several Greek Ottoman subjects to Gloucester College, Oxford, to learn English, with a view to employing them as dragomans on their return, was not repeated. Conversely, more successful and long-lasting was the parallel transformation of the Habsburgs' dragoman training method from a Sprachknaben-Institut (Institute for Language Boys) attached to the Imperial Residence in Istanbul to a Kaiserlich-königliche Akademie für Orientalischer Sprachen (Imperial-Royal Academy for Oriental Languages), which opened in Vienna in I754, though earlier efforts to train dragomans in Vienna date back to I674. Like its Parisian counterpart, the Viennese institution — similarly reliant on Jesuit involvement and pedagogies - proved long-lasting, training some of the greatest dragomans of the late-eighteenth and nineteenth centuries, including Joseph von Hammer-Purgstall, perhaps the most prolific and influential Orientalist of his time. ${ }^{82}$ The French-Habsburg model was also the explicit template for an (ultimately failed) Spanish program to create a School of Oriental Languages in Madrid in $178 \mathrm{I}^{83}$

For the duration of the seventeenth century, however, and lacking systematic apprenticeship programs either on their own soil or in Istanbul, 
most other embassies continued to recruit Greek Orthodox, Armenian, and Jewish dragomans regularly, as well as Catholic graduates of the Venetian and French apprenticeship programs. ${ }^{84}$ Their dragoman cadres, as a result, lacked the strong endogamy and confessional cohesion that characterized the Venetian dragomanate, but perhaps offered ties to wider Ottoman commercial and political networks, particularly given the more dispersed geography of non-Catholic dragomans' places of provenance. ${ }^{85}$

The enduring reliance on local Istanbulite recruits had important implications for the nature of Venetian dragoman apprenticeship. Formally, an apprentice dragoman's training began upon entry into the bailate. But as we saw, many apprentices had started their training long before. As the sons, younger brothers, or nephews of acting dragomans, boys destined for the dragomanate often received language instruction at home in preparation for and in anticipation of their formal admission to the rank of apprentices. At the same time, protracted residency in the bailate proved essential to Venetian dragoman apprenticeships not simply for its role in developing linguistic competence (in both Ottoman Turkish, the employers' written language, and less frequently in Arabic, Persian, or Slavic). It also — perhaps primarily_-served to socialize young men of widely diverse backgrounds into homosocial masculinity and to carefully instill a command of diplomatic protocol premised on a more or less shared, circum-Mediterranean elite courtly culture.

The imperative to cultivate forms of literacy directly tied to elite genres of sociability is well borne out in the memoirs of a consummate French dragoman, François Pétis de la Croix, who wrote ca. I684 that

As for my studies in the Turkish language, I have done in Istanbul the same things I had done in Persia. I have had teachers for language, writing, and music; I have frequented the learned; I have read several good books in prose and in verse. I have endeavored to understand all sorts of legal, financial, and disputational [chicane] records, and even arithmetic, philosophy, and other sciences, and I have studied in the last place the book of a learned man, entitled the Perfect Secretary, which contains letters of all Styles and all characters for kings, princes, viziers, friends, enemies, and all other kinds of conditions. Finally, I tried to learn everything that could be learned from this language and its different characters in Qrmalı, Sulsy and Dyvany, and to make a full exercise of what I had learned, I translated for $\mathrm{Mr}$ 
Ambassador Nointel a quantity of Curious pieces, of which he has charged me, among which were all the letters written beforehand from France to the Ottoman Porte, and from the Porte to the French Court, which comprised a large volume, and several Other books in the languages which I knew, of which this lord has reported to the court. ${ }^{86}$

Pétis de la Croix makes evident that the dragoman's essential work tools went far beyond the (laborious) acquisition of oral fluency in Turkish. Rather, they entailed a deep command of a variety of Ottoman literary genres and a thoroughgoing understanding of official chancery practice, including those inscriptional technologies that contemporary Ottoman bureaucratic elites acquired from similar letter-writing books and exercises. The process of becoming a dragoman, in other words, prepared apprentices to engage with Ottoman officialdom by emulating the very bodily practices (inscription, copying, and translation) and aesthetics of prose literary writing (inşa) that marked a growing cadre of scribes in the contemporary Ottoman divan (chancery). ${ }^{87}$ This was hardly a coincidence, as the functions of embassy dragomans and the imperial divan closely mirrored each other. ${ }^{88}$

In this context, the Venetian apprenticeship program proved relatively effective and enduring not simply thanks to its endogamous elements, but likely because - precisely like the Ottoman training program for scribesit facilitated a community of practice. Membership in this community, cultivated inter alia through prolonged cohabitation in the bailate, underscored the practical and performative aspects of dragomans' habitus. It also fostered greater awareness of the intricacies of elite domestic social hierarchies (which in several fundamental ways were comparable across Ottoman and Venetian elite households) that helped young apprentices navigate the maze of political intrigue and competing interests at the Porte. Here again, apprentices hailing from long-established local dragoman dynasties had a clear advantage over recruits from elsewhere, allowing them to acquire the performative dimensions of the craft from a very young age from their dragoman fathers, uncles, and older siblings. Being part of familial information networks that crossed juridical boundaries and provided access to family archives of translations and copies of essential diplomatic records were also important, if rarely discussed, training resources. Unattached apprentices from faraway Venice and Istria had to rely on the good will of senior dragomans who were understandably 
reticent to share the secrets of their trade, especially if they felt threatened by parvenu younger competitors, or if they sought to secure apprenticeships for their own kin.

More than anything, then, a successful dragoman's apprenticeship was characterized by the acquisition of versatile written and oral genres of communication, by integrating into a community of practice in order to master different aspects of courtly habitus, by learning through emulation how to perform measured deference to a carefully scalar range of local officials and diplomatic representatives, by showing to advantage one's familiarity with Istanbulite elite culture, and by moving across institutional spaces, linguistic registers, and social contexts with "effortless" ease and confidence, embodying Castiglione's much-celebrated ideal of sprezzatura. Beyond linguistic fluency in this or that language, dragomans' extensive apprenticeship, on-the-job training, and long sojourn in Istanbul and in Venetian colonies rather than in Venice proper thus fundamentally shaped their practices of translation and mediation, and proved key to their ability to successfully insert themselves in dense trans-imperial networks of patronage, to become trans-imperial courtiers themselves.

\section{Employment}

If dragomans' trans-imperial provenances and trajectories were ultimately advantageous to the bailate, so were their trans-imperial employment patterns. Perhaps the most distinctive feature of the dragomans' profession was their spatial mobility, often spanning multiple jurisdictions. Embassy dragomans' daily activities were far from limited to interpreting during the bailo's rare formal audiences with the grand vizier and other Ottoman ministers. Rather, they entailed diverse diplomatic, consular, and commercial duties across offices and locales. Dragomans regularly translated written documents to and from Ottoman. Even more frequently, they engaged in independent visits to the imperial divan and to Ottoman officials' residences, where they acted as de facto Venetian representatives in their own right. To perform such duties, they cultivated a dense network of alignments and loyalties in Istanbul, in Venice, and, as important, in other Ottoman commercial hubs and in the Venetian-Ottoman Dalmatian borderlands. ${ }^{89}$ Beyond regular sojourns to the border and short-term assignments to conflict areas, several dragomans were tasked with delicate diplomatic missions further afield - to Persia, North Africa, and the gates 
of Vienna. They recorded these missions in extensive reports, or Relazioni, presented to the Venetian Senate upon their return, much like patrician ambassadors.

Beyond these "exceptional" (and exceptionally well-documented) missions, dragomans also traveled far and wide on more mundane assignments. In fact, assistance in border negotiations and periodic postings throughout Venice's Mediterranean and Adriatic colonies were customary phases in many apprentices' and junior dragomans' training before assuming more prestigious positions in either Venice or Istanbul. The Pera-born Stefano di Gioveni, a dragoman's son who had served the Venetian consul in Alexandria since 158I, was recalled to Istanbul five years later to replace the deceased dragoman Ambrosio Grillo. ${ }^{90}$ The Istanbul-born Giuliano Salvago was sent to Aleppo to serve the Venetian nation there in 1605 , and continued to shuttle back and forth between Aleppo and Istanbul until his premature death in I6I9. ${ }^{91}$ Throughout the seventeenth century, at least half a dozen Istanbul-based dragomans were sent to Venice's maritime headquarters in Zara to work for periods ranging from several months to several years in the service of the Venetian governor-general in Dalmatia, before returning to the Ottoman capital. ${ }^{92}$

While mobility characterized dragomans' trajectories across all ranks, over time, a fairly rigid division of labor emerged to create a hierarchy among specific kinds of dragomans, each associated with different forms of mobility. At the bottom of the pyramid were the giovani di lingua or apprentice dragomans, who were largely confined to the bailate, where their training sometimes morphed into work as they honed their skills by translating incoming Ottoman records and by shadowing more senior members of the corps on their errands. Next was the protogero, a low-level dragoman-clerk in charge of naval and commercial affairs, who spent much of his time at the customs office at the port in Tophane. Higher in status was the dragomanno di strada (road dragoman), entrusted with accompanying Venetian representatives to and from Istanbul, followed by several appointed dragomans (sometimes distinguished by seniority, if not by salary, and referred to, variously, as dragomanno ordinario, dragomanno publico, or simply dragomanno), charged with translation to and from Ottoman and with visiting Ottoman officials and other embassies. The grand dragoman, the most senior of the corps, appeared in audiences in front of the grand vizier and served as the mission's "eyes and ears"-an oft-repeated trope in senior diplomats' reports from their missions. 
In addition, a dragoman-occasionally referred to in the eighteenth century as dragomanno generalizio - was regularly assigned to the Venetian governor-general in Zara, the Venetian colonial headquarters. At least one dragomanno consolare (consular dragoman) was attached to each of the Venetian consulates in Alexandria, Aleppo, and later Izmir. Finally, a dragomanno publico (public dragoman) was also attached to the Cinque Savii alla Mercanzia, Venice's Board of Trade, to help translate incoming correspondence, assist sojourning Ottoman merchants and dignitaries while on Venetian soil, and produce intelligence reports and memoranda concerning Ottoman and Safavid affairs. With few exceptions, all dragomans appointed to this prestigious and lucrative post were Venetian subjects (though not necessarily citizens) with significant prior history of consular service in the Ottoman capital. ${ }^{93}$ Others still, though rarely enjoying the title of dragomans, served in colonial chanceries and courtrooms throughout the Venetian maritime empire, especially in locales with large Greek- and Slavic-speaking populations, such as Corfu, Cyprus, Crete, Dalmatia, and the Istrian peninsula. ${ }^{94}$

Venice's dragomanate was probably the largest in early modern Istanbul, but it was not the only one. Various Ottoman subjects - including Jews, Orthodox Christians, and converts to Islam, served as Porte dragomans, often without formal title, as early as the fifteenth century. ${ }^{95}$ By the late-sixteenth and seventeenth century, Ottoman ad hoc court interpreters were sometimes supplemented with government-appointed chancery dragomans, especially in urban centers throughout the empire's Arabic-, Greek-, and Slavic-speaking provinces. ${ }^{96}$ Like their Venetian counterparts, some Ottoman chancery dragomans stationed in the Ottoman-Habsburg borderlands were involved in border negotiations and other delicate diplomatic missions. ${ }^{97}$ More formalized dragoman positions emerged within the Ottoman administration by the early I670s, including, in addition to the dragoman of the Imperial Council (Divan-ı Hümâyûn tercümani), the dragoman of the fleet (donanma tercümani), who was second in command to the grand admiral, and the dragoman of the Imperial Army (tercüman-ı ordu-yu Hümâyûn). Unlike provincial dragomans who were evidently recruited largely from among the local populace, and who often supplemented their income with tax collecting, the more senior dragoman ranks to emerge in the following century were reserved for Phanariots, were centrally appointed by the Imperial Council, and frequently served as a stepping-stone to even more senior and lucrative positions as voyvodas (viceroys) of Moldavia and Wallachia. ${ }^{98}$ 
Besides the bailate and the Porte, other foreign consulates, too, sought to keep at least one, and often several, dragomans exclusively on their payroll. While generally following the Venetian division of labor, the seniority and power of individual consulate dragomans could not always be gleaned fully from their titles, as there was no necessary correlation between qualifications and career trajectories, let alone age. In fact, as noted earlier, some dragomans were even kept on the payroll for years while essentially not performing any work, simply due to their family connections to other consulates, and therefore out of fear that, if dismissed, they might reveal state secrets to a rival power.

Dragomans' uncertain loyalty was only compounded by their at times mercurial juridical status, which has been the subject of some scholarly debate. Under Ottoman law, local dragomans who served foreign powers enjoyed a special status as beratl, namely the holders of a berat, or patent, which offered distinct tax exemptions, commercial privileges, and freedoms. The ahidname, or imperial charters granted by the sultan to friendly foreign powers, often included several clauses concerning dragomans, enumerating their numbers, privileges, and responsibilities. And whereas the majority of beratl were bona fide dragomans, by the nineteenth century a certain number enjoyed this status without performing any actual diplomatic duties, contributing in no small measure to the reputation of the system as corrupt and unsustainable. Ottoman authorities themselves sought to limit the number of dragomans allotted to each embassy for precisely this reason. Dragomans' legal immunities as "subjects" of their employers (even as the vast majority were born Ottoman subjects) exacerbated an already complex situation..$^{99}$

The ambiguity of dragomans' legal status was nowhere more apparent than in their fraught relationship to the bailate as an institution that provided them with coveted legal privileges and which bolstered their standing in the community, but whose own modes of authority vitally depended on the cultivation of myriad patronage bonds with dragomans' own independent households throughout the capital. It is to these households, and their profound role in shaping the dragomanate's lifeworlds, that we now turn. 